\title{
Chylomicrons Alter the Fate of Endotoxin, Decreasing Tumor Necrosis Factor Release and Preventing Death
}

\author{
Hobart W. Harris, " Carl Grunfeld, " Kenneth R. Feingold, " Thomas E. Read, * John P. Kane," \\ Albert L. Jones," Eldan B. Eichbaum, * Gregory F. Bland, ** and Joseph H. Rapp* \\ * Department of Surgery and Cardiovascular Research Institute, University of California, San Francisco (UCSF), and Surgical Service, \\ Department of Veterans Affairs, San Francisco (DVAMCSF); ${ }^{\ddagger}$ Department of Medicine and Liver Center, UCSF, and Metabolism \\ Section, DVAMCSF; ${ }^{\S}$ Department of Medicine, UCSF, and Metabolism Section, DVAMCSF; "Department of Medicine, Biochemistry \\ and Biophysics and Cardiovascular Research Institute, UCSF; 'Cell Biology Section, DVAMCSF, and Department of Medicine and \\ Liver Center, UCSF; and **Department of Surgery, UCSF, San Francisco, California 94143, and Cell Biology Section, DVAMCSF, \\ San Francisco, California 94121
}

\begin{abstract}
The hypertriglyceridemia of infection was traditionally thought to represent the mobilization of substrate to fuel the body's response to the infectious challenge. However, we have previously shown that triglyceride-rich lipoproteins can protect against endotoxin-induced lethality. The current studies examine the mechanism by which this protection occurs. Rats infused with a lethal dose of endotoxin preincubated with chylomicrons had a reduced mortality compared with rats infused with endotoxin alone (15 vs. 76\%, $P<0.001)$. Preincubation with chylomicrons increased the rate of clearance of endotoxin from plasma and doubled the amount of endotoxin cleared by the liver $(30 \pm 1$ vs. $14 \pm 2 \%$ of the total infused radiolabel, $P$ $<0.001$ ). In addition, autoradiographic studies showed that chylomicrons directed more of the endotoxin to hepatocytes and away from hepatic macrophages. Rats infused with endotoxin plus chylomicrons also showed reduced peak serum levels of tumor necrosis factor as compared with controls (14.2 \pm 3.3 vs. 44.9 $\pm 9.5 \mathrm{ng} / \mathrm{ml}$, mean $\pm \mathrm{SEM}, P=0.014)$. In separate experiments, chylomicrons $(1,000 \mathrm{mg}$ triglyceride $/ \mathrm{kg})$ or saline were infused $10 \mathrm{~min}$ before the infusion of endotoxin. Chylomicron pretreatment resulted in a reduced mortality compared with rats infused with endotoxin alone ( 22 vs. $78 \%, P<0.005)$. Therefore, chylomicrons can protect against endotoxin-induced lethality with and without preincubation with endotoxin. The mechanism by which chylomicrons protect against endotoxin appears to involve the shunting of endotoxin to hepatocytes and away from macrophages, thereby decreasing macrophage activation and the secretion of cytokines. (J. Clin. Invest. 1993. 91:1028-1034.) Key words: lipoproteins • triglycerides • lipopolysaccharide $\bullet$ cytokines $\bullet$ liver
\end{abstract}

\section{Introduction}

The host responds to bacterial, viral, fungal, and parasitic infection with the secretion of cytokines, which mediate the host's immunologic response by recruiting cells and activating a variety of cellular functions (1-3). In addition, cytokines

Address reprint requests to Dr. Joseph H. Rapp, Surgical Service (112), Department of Veterans Affairs Medical Center, 4150 Clement Street, San Francisco, CA 94121.

Received for publication 21 February 1992 and in revised form 25 September 1992.

The Journal of Clinical Investigation, Inc.

Volume 91, March 1993, 1028-1034 mediate the acute phase response, a change in the hepatic synthetic program with increased production of acute phase proteins that aid host defense (4-7). The host response to infection also includes cytokine-mediated changes in intermediary metabolism such as hypertriglyceridemia $(8,9)$, which is due to both increases in hepatic triglyceride-rich lipoprotein synthesis $(10,11)$ and decreases in lipoprotein lipase-mediated lipoprotein clearance $(12,13)$.

The increased production of triglyceride-rich lipoproteins by the liver is now postulated to be a part of the acute phase response, as lipoproteins serve not only as a potential source of metabolic fuel (14) but also as direct participants in the protective process. All lipoproteins, including cholesterol-rich HDL (15-20) and LDL (18-20) and triglyceride-rich VLDL and chylomicrons $(19,20)$, have been shown to bind endotoxin, subsequently reducing its toxic properties. Recent data from our laboratory has demonstrated a dose-dependent increase in mouse survival when varying concentrations of either VLDL or chylomicrons were incubated with a lethal dose of Escherichia coli endotoxin before its intraperitoneal injection (20). In addition, we found that in normal humans triglyceride-rich lipoproteins contained detectable levels of endogenous endotoxin that was presumably scavenged in vivo (20).

The purpose of this study was to examine the mechanism by which triglyceride-rich lipoproteins afford protection from endotoxemia. In these experiments we measured survival, and the clearance, hepatic uptake, tissue distribution of endotoxin, and serum levels of TNF in rats infused with a lethal dose of endotoxin that had been incubated with either nascent rat chylomicrons or normal saline. We also examined whether protection from endotoxic shock could be afforded by infusion of chylomicrons in vivo before administration of endotoxin.

\section{Methods}

Reagents and solutions. Reagent grade ortho-phosphoric acid (Fisher Chemical Co., Fairlawn, NJ) and $\mathrm{NaOH}$ (J. T. Baker Chemical Co., Phillipsburg, NJ); apyrogenic, preservative-free $0.9 \% \mathrm{NaCl}$ (Kendall McGraw Labs, Inc., Irvine, CA) and $\mathrm{H}_{2} \mathrm{O}$ (Elkins-Sinn, Inc., Cherry Hill, NJ); D-galactosamine hydrochloride (Sigma Chemical Co., St. Louis, MO) were used as specified. The PBS used in all experiments was tested and found free of detectable endotoxin.

E. coli, strain 055:B5 endotoxin (Difco Laboratories, Detroit, MI) was reconstituted with sterile, apyrogenic $\mathrm{H}_{2} \mathrm{O}$ to a concentration of 1 $\mu \mathrm{g} / \mathrm{ml}$ and stored in $3-\mathrm{ml}$ aliquots at $-70^{\circ} \mathrm{C}$. This preparation of endotoxin was isolated via the Westphal technique (phenol extraction) (21) and had a specific activity of 15 endotoxin units/ng (United States Pharmaceutical reference endotoxin ). 
Depyrogenation. To avoid contamination with exogenously derived endotoxin, all heat-stable materials used in the isolation, processing, and assay of solutions to be injected into the rats were rendered sterile and free of detectable endotoxin $(\leq 5-10 \mathrm{pg} / \mathrm{ml})$ by previously reported methods (20).

Mesenteric lymph collection. Male Sprague-Dawley rats (200-300 g) were obtained from Bantin and Kingman, Inc. (Fremont, CA). Special precautions, as previously noted $(20)$, were taken to avoid the introduction of exogenous endotoxin during the collection process. To collect mesenteric lymph, rats received a gavage feeding of 3-4 $\mathrm{ml}$ of a $1: 3(\mathrm{vol} / \mathrm{vol})$ corn oil to nonfat dry milk mixture. Approximately $1 \mathrm{~h}$ after the feeding a right flank incision was performed under sodium pentobarbital anesthesia $(25-40 \mathrm{mg} / \mathrm{kg}$ i.p. $)$, the lipemic mesenteric lymph duct identified, and cannulated with $P E 50$ polyethylene tubing under $2 \times$ magnification. The tubing was secured in place with liquid glue, the flank incision closed, and the animal recovered in a restriction cage. Lymph production was promoted by the subcutaneous injection of sterile saline $(20 \mathrm{cc} / \mathrm{kg})$ and the lymph was collected into sterile, endotoxin-free flasks in an ice bath for 4 to $6 \mathrm{~h}$, after which the animals were killed. The mesenteric lymph was stored at $4^{\circ} \mathrm{C}$ and used within $72 \mathrm{~h}$ of its collection. The lymph preparations contained no demonstrable apoprotein B-100 (VLDL) by Coomassie staining of gels after polyacrylamide gel electrophoresis (data not shown). The triglyceride content of the mesenteric lymph was determined using a standard enzymatic assay (Sigma Chemical Co.).

Radioiodination. Endotoxin was radiolabeled with ${ }^{125} \mathrm{I}$ by the method of Ulevitch (22). Briefly, E. coli (055:B5) endotoxin was first derivatized by reacting with $p-\mathrm{OH}$ methylbenzimidate at alkaline $\mathrm{pH}$, and then labeled with $\mathrm{Na}^{125} \mathrm{I}$. The ${ }^{125} \mathrm{I}$-endotoxin had a specific activity of $1.96-2.30 \mu \mathrm{Ci} / \mu \mathrm{g}$.

Lethality studies. Male Sprague-Dawley rats (180-225 g) were infused with a lethal dose of $E$. coli (055:B5) endotoxin via an ileofemoral venous catheter. The endotoxin was incubated with either rat mesenteric lymph containing nascent chylomicrons (endotoxin plus chylomicrons, $500 \mathrm{mg}$ chylomicron triglyceride $/ \mathrm{kg}$ ) or an equal volume of normal saline (endotoxin alone) at $37^{\circ} \mathrm{C}$ for $3 \mathrm{~h}$ before its administration. An intravenous dose of D-galactosamine $(375 \mathrm{mg} / \mathrm{kg}$ ) was given just before the endotoxin infusion. The rat mortality rate was determined over a 48-h period during which food and water were provided ad libitum.

In a second experimental protocol, male Sprague-Dawley rats $(180-225 \mathrm{~g})$ were infused with either chylomicrons $(1,000 \mathrm{mg}$ triglyceride $/ \mathrm{kg}$ ) or an equivalent volume of saline followed by a separate injection of a lethal dose of $E$. coli (055:B5) endotoxin via an ileofemoral venous catheter $\sim 10 \mathrm{~min}$ later. As described above, an intravenous dose of D-galactosamine was administered and the rat mortality rate was determined at $48 \mathrm{~h}$.

Plasma clearance of endotoxin-chylomicron complexes. Male Sprague-Dawley rats $(314 \pm 21 \mathrm{~g})$ were infused with a lethal dose of $E$. coli $(055: \mathrm{B} 5){ }^{125} \mathrm{I}$-labeled endotoxin, $14 \mu \mathrm{g} / \mathrm{kg}$, sp act $=1.96 \mu \mathrm{Ci} / \mu \mathrm{g}$, via an ileofemoral venous catheter. The endotoxin was incubated with either rat mesenteric lymph containing nascent chylomicrons, (endotoxin plus chylomicrons, $500 \mathrm{mg}$ chylomicron triglyceride $/ \mathrm{kg}$ ) or an equal volume of normal saline (endotoxin alone) as previously described. D-Galactosamine $(375 \mathrm{mg} / \mathrm{kg})$ was given intravenously just before the endotoxin infusion. Serial blood samples were obtained via rat tail vein and assayed for ${ }^{125} \mathrm{I}$ by gamma counting.

Plasma clearance of chylomicron triglyceride. Male Sprague-Dawley rats $(250-280 \mathrm{~g})$ received an intravenous infusion of nascent chylomicrons, either 500 or $1,000 \mathrm{mg}$ chylomicron triglyceride $/ \mathrm{kg}$. Serial blood samples were obtained from an ileofemoral venous catheter. Plasma triglyceride levels were determined using a standard enzymatic assay (Sigma Chemical Co.).

Tissue distribution. Male Sprague-Dawley rats (180-200 g) were infused with a lethal dose of $E$. coli $(055: \mathrm{B} 5)^{125}$ I-labeled endotoxin, 14 $\mu \mathrm{g} / \mathrm{kg}$, sp act $=2.30 \mu \mathrm{Ci} / \mu \mathrm{g}$, via an ileofemoral venous catheter. The endotoxin was incubated with either rat mesenteric lymph containing nascent chylomicrons, (endotoxin plus chylomicrons, $500 \mathrm{mg}$ chylo- micron triglyceride $/ \mathrm{kg}$ ) or an equal volume of normal saline (endotoxin alone) as previously described. D-Galactosamine $(375 \mathrm{mg} / \mathrm{kg})$ was given intravenously just before the endotoxin infusion. $45 \mathrm{~min}$ after the endotoxin infusion the rats were killed. Each animal's liver, spleen, heart, adipose tissue, skeletal muscle, and blood were harvested and assayed for ${ }^{125} \mathrm{I}$ by gamma counting.

To determine the potential effect of D-galactosamine on the tissue distribution of ${ }^{125}$ I-endotoxin in our animal model, experiments identical to those above were also performed in the absence of D-galactosamine.

Intrahepatic localization of ${ }^{125}$ I-endotoxin. Animals were infused with ${ }^{125} \mathrm{I}$-endotoxin alone or ${ }^{125} \mathrm{I}$-endotoxin plus chylomicrons, as described in the tissue distribution studies. $45 \mathrm{~min}$ after endotoxin infusion the animals' livers were perfusion fixed according to the technique of St. Hilaire et al. (23). Subsequent to perfusion fixation, hepatic biopsies were obtained from each lobe and immersed in additional fresh fixative for $2 \mathrm{~h}$, rinsed overnight in $0.2 \mathrm{M}$ sodium bicarbonate buffer, and embedded in paraffin. 5-7- $\mu \mathrm{m}$ thick sections were cut, mounted on glass slides, and coated with photographic emulsion. After an identical exposure time of $\sim 3 \mathrm{wk}$, all of the slides were developed and stained with hematoxylin and eosin. The silver grains were visually inspected at $\times 40(23)$. To more closely examine liver histology, 3- $\mu \mathrm{m}$ thick sections were also cut, mounted on glass slides, and stained with hematoxylin and eosin.

$T N F$ assay. To determine the peak serum TNF concentration in the rats, a blood sample (300-500 $\mu \mathrm{l}$ ) was obtained via tail vein $90 \mathrm{~min}$ after the endotoxin infusion. In brief, serum TNF levels were measured via a cytotoxicity assay using WEHI 164 clone 13 cells with development using MTT Tetrazolium (24). No TNF was detected in the serum of rats that did not receive endotoxin.

Statistical analysis. Statistical significance for the mortality data was determined by Chi-square analysis. Plasma clearance, tissue distribution, and serum TNF levels were compared using Students' $t$ test.

\section{Results}

Effect of preincubating chylomicrons with endotoxin on endotoxin-induced death. Control animals receiving endotoxin plus saline experienced a $76 \%$ mortality rate at $48 \mathrm{~h}$ as compared with a $15 \%$ mortality rate for rats receiving endotoxin plus chylomicrons (Table I, $P<0.001$ ). Most of the control animals appeared ill within $4 \mathrm{~h}$ of the endotoxin injection and died within $36 \mathrm{~h}$. In contrast, the rats that received preincubated chylomicron-endotoxin complexes frequently appeared ill during the early hours of the study but were generally fully recovered by the end of the observation period.

Effect of pretreating rats with chylomicrons on endotoxininduced death. Chylomicrons did not have to be incubated with endotoxin before injection to be protective; however, to

Table I. Protection of Rats from Endotoxin-induced Death by Infusion of Chylomicron-Endotoxin Complexes

\begin{tabular}{lcc}
\hline \multicolumn{1}{c}{ Treatment group } & Mortality at 48 h & [TNF] \\
\hline & & $n g / m l$ \\
Saline (control) & $22 / 29(75.9 \%)$ & $44.9 \pm 9.5(n=10)$ \\
Chylomicron bound & $4 / 26(15.4 \%)^{\ddagger}$ & $14.2 \pm 3.3(n=9)^{8}$
\end{tabular}

Rats were infused with a lethal dose of $E$. coli endotoxin. The endotoxin was incubated with either rat mesenteric lymph containing nascent chylomicrons (chylomicron bound) or an equal volume of normal saline (control) for $3 \mathrm{~h}$ before the endotoxin infusion. Mortality rate was determined over a 48-h period. Blood was drawn for serum TNF levels $90 \mathrm{~min}$ after endotoxin infusion. * Mean \pm SEM. ${ }^{\ddagger} P<0.001$. ${ }^{\S} P=0.014$. 
achieve the same degree of protection observed with preincubation, the quantity of chylomicron triglyceride infused had to be doubled ( $1 \mathrm{~g}$ chylomicron triglyceride $/ \mathrm{kg}$ ). Rats pretreated with saline followed by endotoxin experienced a $78 \%$ mortality rate at $48 \mathrm{~h}$ as compared with a $22 \%$ mortality rate for rats pretreated with chylomicrons $(14 / 18$ vs. $4 / 18, P<0.005)$ (Fig. 1). Thus, circulating triglyceride-rich lipoproteins can protect rats against exogenously administered endotoxin.

Effect of chylomicrons on the plasma clearance of ${ }^{125}$ I-endotoxin. To examine the clearance of endotoxin in our rodent model, two groups of rats received endotoxin infusions preincubated with chylomicrons or saline in a manner identical to the mortality experiments reported above except these infusions contained ${ }^{125} \mathrm{I}$-labeled endotoxin. Endotoxin plus chylomicrons were cleared more rapidly from the circulation than endotoxin plus saline, with both showing a biphasic clearance pattern (Fig. 2).

Plasma clearance of chylomicron triglyceride. The infusion of $500 \mathrm{mg}$ chylomicron triglyceride/ $\mathrm{kg}$ produced a plasma triglyceride concentration of $883 \pm 74 \mathrm{mg} / \mathrm{dl} 5 \mathrm{~min}$ after infusion. Plasma triglyceride was rapidly cleared, falling to $148 \pm 13 \mathrm{mg}$ / dl $1 \mathrm{~h}$ after infusion. Similarly, the infusion of $1,000 \mathrm{mg}$ chylomicron triglyceride $/ \mathrm{kg}$ produced an early rise in plasma triglyceride concentration $(4,700 \pm 624 \mathrm{mg} / \mathrm{dl} 5 \mathrm{~min}$ after chylomicron infusion, which was just before endotoxin administration ). Again, plasma triglyceride was rapidly cleared, falling to $1,067 \pm 296 \mathrm{mg} / \mathrm{dl} 1 \mathrm{~h}$ after infusion, and to $115 \pm 46 \mathrm{mg} / \mathrm{dl} 2 \mathrm{~h}$ after infusion. (Data expressed as the mean of four animals \pm SEM in each group.)

Effect of chylomicrons on the tissue distribution of ${ }^{125}$ I-endotoxin. Rats were infused with ${ }^{125} \mathrm{I}$-endotoxin plus either chylomicrons or saline and killed $45 \mathrm{~min}$ after the endotoxin infusion. Of the various tissues that were harvested and assayed, liver, blood, and skeletal muscle revealed significant differences in the content of radiolabel in animals that received labeled endotoxin plus chylomicrons versus those animals that received labeled endotoxin alone (Fig. $3 \mathrm{~A}$ ). The ${ }^{125} \mathrm{I}$ content of livers from rats that received endotoxin plus chylomicrons were increased twofold over that of livers from saline-treated

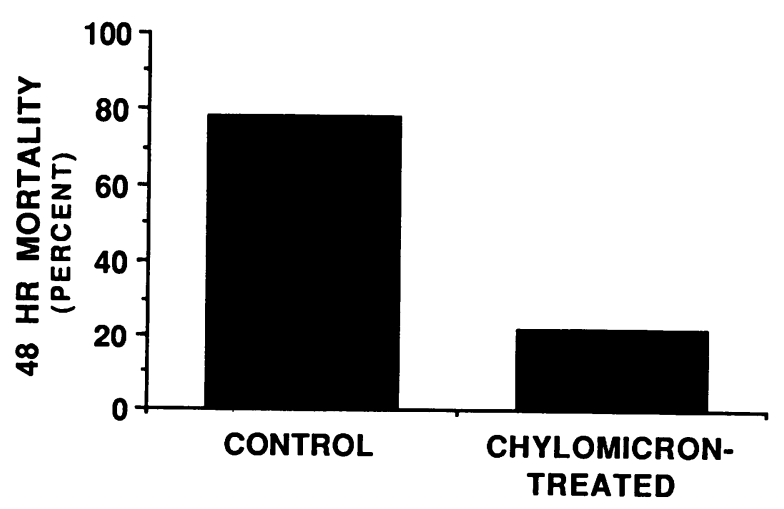

Figure 1. Protection of rats from endotoxin-induced death by pretreatment with chylomicrons. Rats were infused with a lethal dose of $E$. coli endotoxin. $10 \mathrm{~min}$ before the endotoxin infusion, the animals received an intravenous infusion of either rat mesenteric lymph containing nascent chylomicrons (chylomicron-treated) or an equal volume of normal saline (controls). D-galactosamine was given just before endotoxin. Mortality was determined at $48 \mathrm{~h}$. ( $n=18$ for each group, $P<0.005$.)

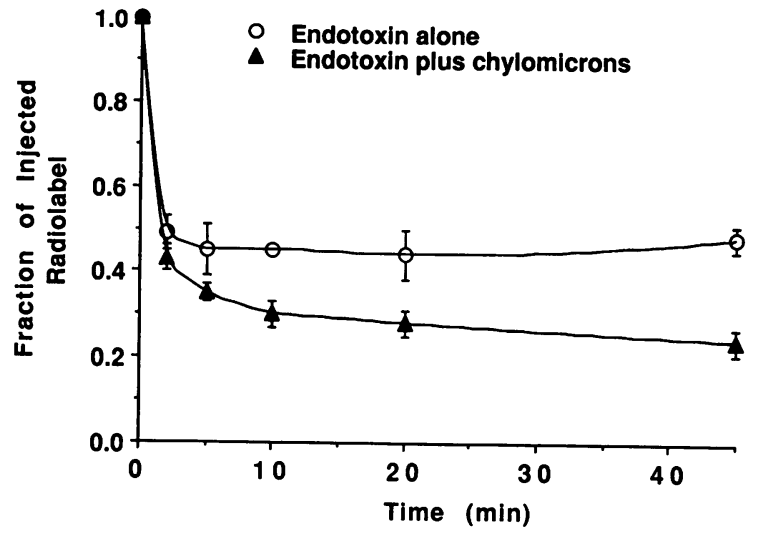

Figure 2. Plasma clearance of endotoxin-chylomicron complexes. Rats were infused with a lethal dose of $E$. coli ${ }^{125}$ I-labeled endotoxin. The endotoxin was incubated with either rat mesenteric lymph containing nascent chylomicrons (endotoxin plus chylomicrons) or an equal volume of normal saline (endotoxin alone). D-galactosamine was given just before endotoxin. Serial blood samples were obtained and assayed for ${ }^{125} \mathrm{I}$ by gamma counting. The data are the mean $\pm \mathrm{SD}$ from four animals.

rats ( $30 \pm 1$ vs. $14 \pm 2 \%$ of total infused radiolabel, respectively, $P<0.001$ ). Conversely, the contents of radiolabel in blood and skeletal muscle from rats treated with endotoxin plus chylomicrons were decreased by 50 and $40 \%$, respectively, as compared with rats treated with endotoxin alone.

When the identical experiment was conducted without administration of D-galactosamine, a similar distribution pattern of ${ }^{125}$ I-endotoxin into liver and blood was observed (Fig. $3 \mathrm{~B}$ ). The ${ }^{125}$ I content of livers from rats that received endotoxin plus chylomicrons was increased twofold over that of livers from saline-treated rats $(43 \pm 1$ vs. $19 \pm 8 \%$ of total infused radiolabel, respectively, $P<0.03$ ). Conversely, the contents of radiolabel in blood from rats treated with endotoxin plus chylomicrons was decreased by $80 \%$ as compared with rats treated with endotoxin alone ( $5 \pm 1$ vs. $31 \pm 5 \%$ of total infused radiolabel, $P$ $<0.003$ ).

Effect of chylomicrons on the intrahepatic localization of ${ }^{125}$ I-endotoxin. Hepatic autoradiographs were obtained $45 \mathrm{~min}$ after rats were infused with ${ }^{125}$ I-endotoxin plus either saline or chylomicrons. After endotoxin plus saline was infused, the majority of the radiolabel in the liver was clustered over perisinusoidal cells resembling Kupffer cells, rarely over hepatocytes (Fig. $4 \mathrm{~A}$ ). These results are consistent with those from other laboratories, suggesting that endotoxin is normally cleared by the reticuloendothelial system, especially by Kupffer cells (2529 ). However, after the infusion of endotoxin plus chylomicrons there was both a striking increase in radiolabel overlying hepatocytes and a relative decrease in the density of the label clustered over Kupffer cells (Fig. $4 \mathrm{~B}$ ).

Light microscopic examination of the $3-\mu \mathrm{m}$-thick sections stained with hematoxylin and eosin alone revealed no evidence of significant hepatocellular damage in both controls and chylomicron-treated animals.

Effect of chylomicrons on endotoxin-induced TNF production. Hepatocytes, unlike macrophages, are not known to produce TNF or other cytokines when exposed to endotoxin and thus the shunting of endotoxin toward hepatocytes and away from macrophages could presumably result in reduced cyto- 
A
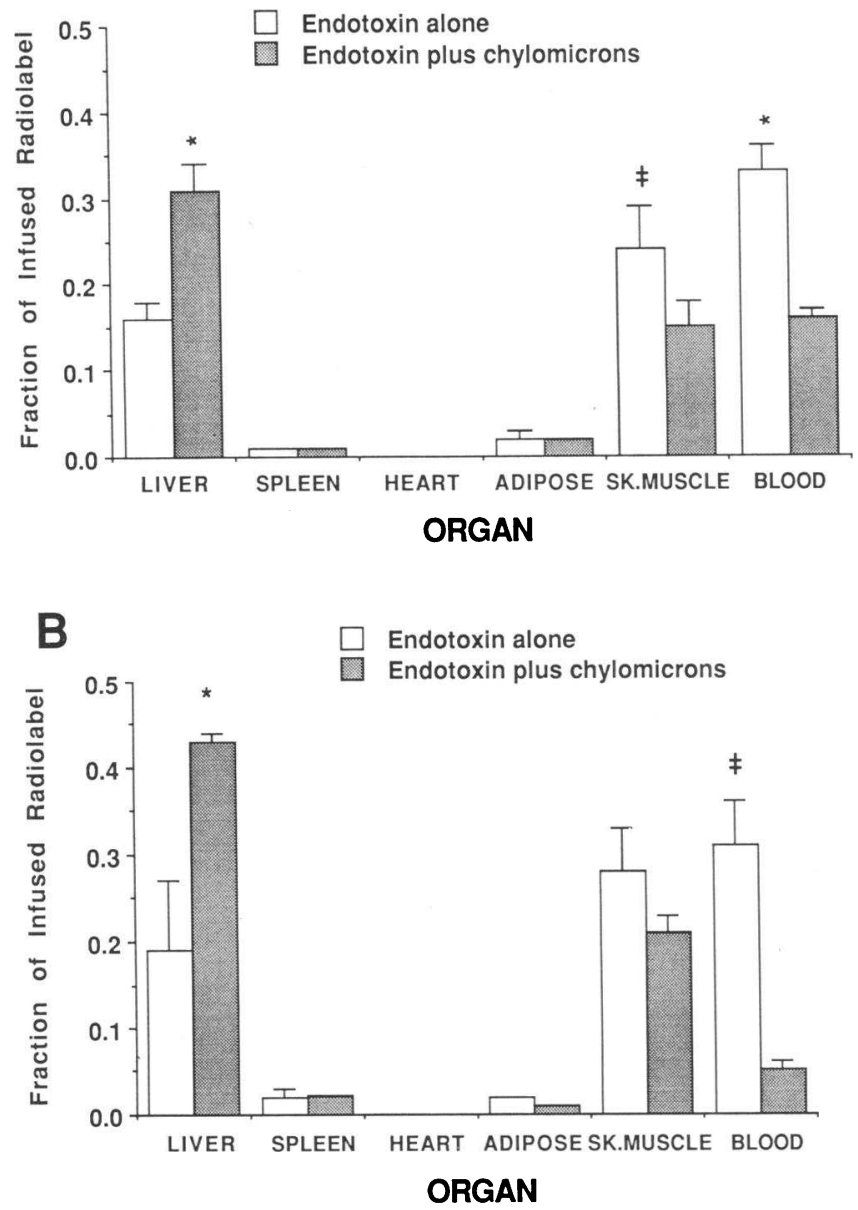

Figure 3. Tissue distribution of endotoxin-chylomicron complexes. Rats were infused with a lethal dose of $E$. coli ${ }^{125}$ I-labeled endotoxin. The endotoxin was incubated with either rat mesenteric lymph containing nascent chylomicrons (endotoxin plus chylomicrons) or an equal volume of normal saline (endotoxin alone). $45 \mathrm{~min}$ after the endotoxin infusion the rats were killed. Each animal's liver, spleen, heart, adipose tissue, skeletal muscle, and blood were harvested and assayed for ${ }^{125}$ I by gamma counting. The data are the mean \pm SEM obtained from five animals. ${ }^{*},{ }^{\ddagger}$ significantly different from control, ${ }^{*} P<0.001,{ }^{\ddagger} P<0.009$. ( $\left.A\right)$ Animals received D-galactosamine just before endotoxin infusion; $(B)$ D-galactosamine withheld.

kine elaboration. Since cytokines mediate the lethal effects of endotoxemia (30-32), a reduction in circulating cytokine levels would result in reduced endotoxin lethality.

The peak serum concentration of TNF was measured to determine whether chylomicrons reduce the circulating level of endotoxin-induced cytokines in our animal model. Rats receiving endotoxin plus chylomicrons had a $68 \%$ reduction in serum TNF levels 90 min after infusion as compared with rats receiving endotoxin alone $(14.2 \pm 3.3$ vs. $44.9 \pm 9.5 \mathrm{ng} / \mathrm{ml}$, respectively, mean \pm SEM, $P=0.014$, Table I). When one compares the serum TNF levels in all of the rats that survived versus all of those that died from both groups, regardless of whether they received chylomicrons or saline, there is a significant difference in TNF levels (survived $15.2 \pm 4.1$ vs. died $44.1 \pm 9.6 \mathrm{ng} / \mathrm{ml}, P=0.02$ ). This difference further highlights the role of TNF in mediating the toxicity of endotoxin.

\section{Discussion}

We hypothesized that chylomicrons may protect against endotoxin-induced lethality by altering endotoxin's metabolism. These data show that intravenous administration of endotoxin after preincubation with chylomicrons $(a)$ protects against endotoxin-induced death in rats; $(b)$ increases the clearance rate of endotoxin from plasma; $(c)$ alters endotoxin's tissue distribution; $(d)$ increases the hepatocellular uptake of endotoxin, while shunting endotoxin away from Kupffer cells; and $(e)$ reduces peak serum levels of TNF, a macrophage/Kupffer cell product. Hence, triglyceride-rich lipoproteins can redirect the metabolism of endotoxin, thereby affording protection against this toxic macromolecule. In addition, we have shown that preincubation of chylomicrons with endotoxin is not necessary to achieve the protective effect, although preincubation does reduce the quantity of chylomicron triglyceride required for this protection.

Previous studies examining endotoxin metabolism have demonstrated that the reticuloendothelial system is primarily responsible for the clearance of endotoxin from the circulation $(25,26)$. In particular, hepatic macrophages (Kupffer cells) appear to be the predominant cell type involved in the clearance process $(27-30)$. We hypothesized that the binding of endotoxin to chylomicrons alters this toxic macromolecule's metabolism and tissue distribution. Specifically, the catabolism of an endotoxin-chylomicron complex is directed by the chylomicron not by the endotoxin molecule. Since chylomicrons are rapidly cleared from the circulation by hepatocytes $(33,34)$, the endotoxin-chylomicron complex would also be cleared from the circulation by hepatocytes instead of macrophages in the liver (Kupffer cells), spleen, and splanchnic bed.

Work in our laboratory and others has demonstrated an interaction between triglyceride-rich lipoproteins and endotoxin, both in vitro (35-37) and in vivo (20). In addition, there is evidence that human VLDL may bind endogenous endotoxin in vivo (20). Specifically, VLDL harvested from healthy normolipidemic volunteers frequently revealed detectable levels of endotoxin. The cholesterol ester-rich LDL and HDL also have been shown to decrease endotoxin-induced toxicity in rodents $(15,18,20,38)$. The complexing of endotoxin to these cholesterol ester-rich lipoproteins may also redirect their fate (39).

As demonstrated here, when chylomicrons increase the amount of endotoxin delivered to the hepatocyte, there is a concomitant decrease in plasma TNF levels, a cytokine that is a known mediator of endotoxic shock $(30,31)$. It is possible that the levels of other cytokines involved in shock, such as IL-1 (32), may also be decreased. The binding of endotoxin to lipoproteins in vitro prevents endotoxin-induced activation of monocyte/macrophages and secretion of TNF, IL-1, and IL-6 $(40,41)$. The apparent increase in endotoxin delivered to hepatocytes could result in some degree of cellular toxicity. We did not observe such hepatocellular toxicity at the 45-min time point. However, this remains an important theoretical concern as it could limit the repeated administration of chylomicrons in a sepsis model, where there is ongoing release of endotoxin. D-Galactosamine toxicity also may be a confounding factor in this model, possibly altering the ability of hepatocytes to eliminate endotoxin via bile (42).

The interaction between lipoproteins and endotoxin may represent another nonlipid transport, antiinfectious function 

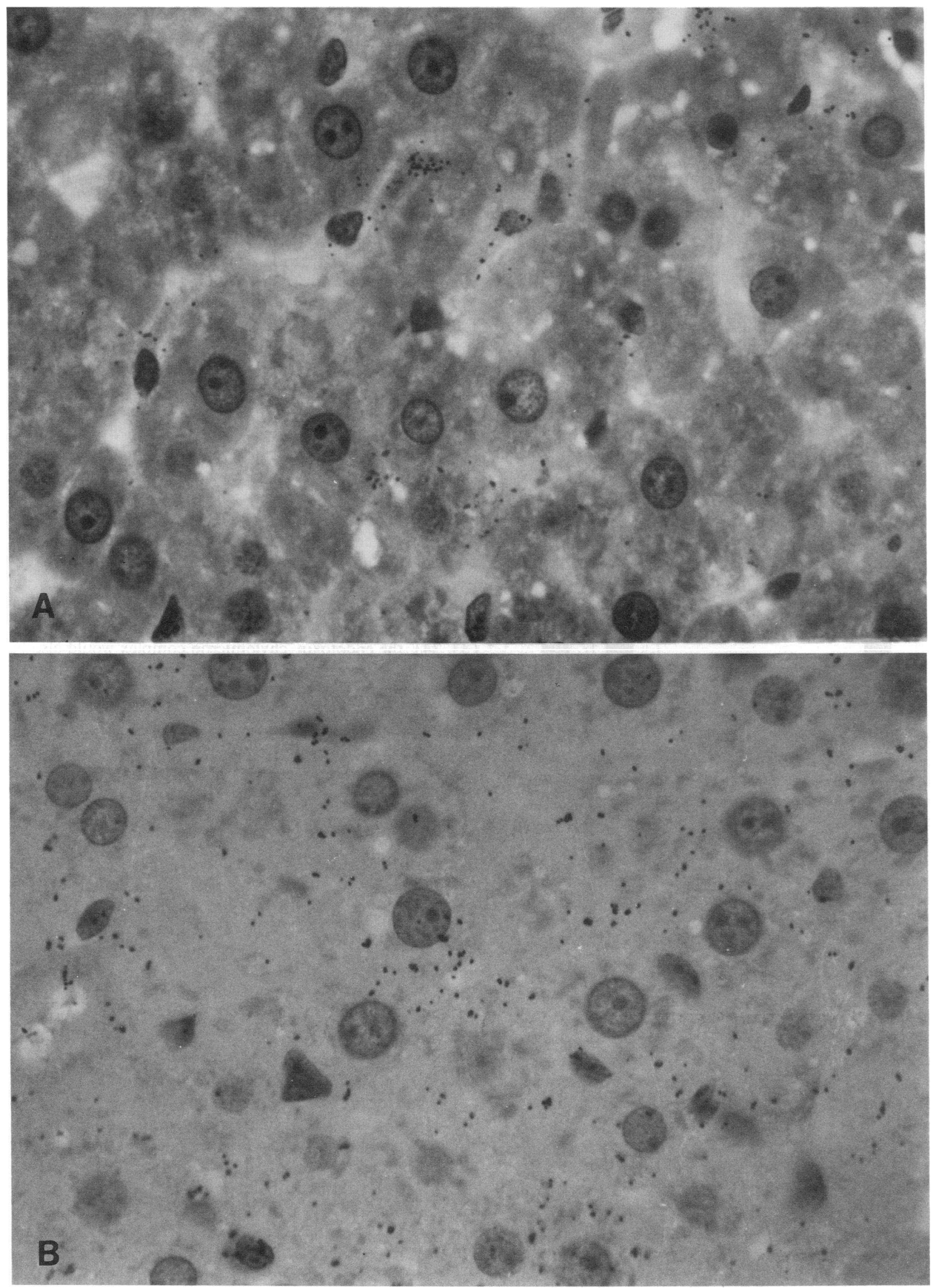

Figure 4. Intrahepatic localization of ${ }^{125} \mathrm{I}$-endotoxin. Animals were infused with ${ }^{125} \mathrm{I}$-endotoxin alone $(A)$ or ${ }^{125} \mathrm{I}$-endotoxin plus chylomicrons $(B)$. D-galactosamine was given just before endotoxin. After $45 \mathrm{~min}$ their livers were perfusion fixed and hepatic biopsies were obtained from each lobe and embedded in paraffin. 5-7- $\mu \mathrm{m}$-thick sections were cut, mounted on glass slides, and coated with photographic emulsion. After an identical exposure time of $\sim 3 \mathrm{wk}$, all of the slides were developed and stained with hematoxylin and eosin. The silver grains were visually inspected at $\times 40(23)$. 
for lipoproteins. Lipoproteins have been found to be potent inhibitors of the infectivity of the murine xenotropic type $\mathrm{C}$ virus (43), Japanese encephalitis (44), Epstein-Barr virus (45), rabies virus, and vesicular stomatitis virus (46). Apolipoprotein A-I, the predominant apoprotein found in HDL, has recently been shown to prevent fusion of the human immunodeficiency virus with cells (47). HDL also have powerful antiparasitic activity as they can effectively lyse and kill Trypanosoma brucei (48-50). Lipoproteins also decrease the inflammatory response to monosodium urate crystals (51). Thus, lipoproteins can decrease the toxicity of a variety of harmful biological and chemical agents.

Recently, an increasing roster of cytokines that are induced by a variety of infectious and inflammatory conditions have been shown to mediate changes in lipid metabolism (9). TNF $(9,52-54)$, the interferons $(9,52,54,55)$, IL-1 $(9,55-57)$, and IL-6 (58) are among those that can increase hepatic fatty acid and lipoprotein synthesis or decrease lipoprotein lipase and lipid storage by adipocytes. These processes would increase plasma concentrations of triglyceride-rich lipoproteins or at least maintain their level despite infection (cytokine)-induced anorexia. Our data and that of others suggest that the triglyceride-rich lipoproteins may play a central role in the clearance and neutralization of endotoxin and viruses. The multiple humoral stimuli that converge on this system to maintain lipoprotein levels during infection attest to its critical function in host defense.

\section{Acknowledgments}

The advice of Robert I. Roth and Jack Levin, and the able technical assistance of Judy Tweedie-Hardman are greatly appreciated.

This work was supported by grants from the Research Service of the Department of Veterans Affairs, the Awards for Research Scientists (ARCS) Foundation, and the National Institutes of Health (HL41470, HL-07737, HL-14237, DK-40990, DK-38436, DK-25828, and DK-26743).

\section{References}

1. Buron, S., F. Dianzani, and G. J. Stanton, editors. 1981. The Interferon System: A Review to 1982, Parts I and II. Tex. Rep. Biol. Med. 41:1-715.

2. Dinarello, C. A. 1989. Interleukin-1 and its biologically related cytokines. Adv. Immunol. 44:153-205.

3. Oppenheim, J. J., and S. Cohen, editors. 1983. Interleukins, lymphokines, and cytokines. Proc. 3rd Int. Lymphokine Workshop. Academic Press, Inc., New York. 441-446.

4. Perlmutter, D. H., C. A. Dinarello, P. I. Punsal, and H. R. Colten. 1986. Cachectin/tumor necrosis factor regulates hepatic acute-phase gene expression. J. Clin. Invest. 78:1349-1354.

5. Darlington, G. J., D. R. Wilson, and L. B. Lachman. 1986. Monocyte-conditioned medium, interleukin-1, and tumor necrosis factor stimulate the acute phase response in human hepatoma cells in vitro. J. Cell Biol. 103:787-793.

6. Castell, J. V., M. J. Gómez-Lechón, M. David, T. Andus, T. Geiger, R. Trullenque, R. Fabra, and P. C. Heinrich. 1989. Interleukin-6 is the major regulator of acute phase protein synthesis in adult human hepatocytes. FEBS (Fed. Eur. Biochem. Soc.) Lett. 242:237-239.

7. Marinkovic, S., G. P. Jahreis, G. G. Wong, and H. Baumann. 1989. IL-6 modulates the synthesis of a specific set of acute phase plasma proteins in vivo. $J$. Immunol. 142:808-812.

8. Beisel, W. R. 1975. Metabolic response to infection. Annu. Rev. Med. 26:9-20.

9. Grunfeld, C., and K. R. Feingold. 1991. The metabolic effects of tumor necrosis factor. Biotherapy. 3:143-148.

10. Gukian, J. D. 1973. Role of metabolism in pathogenesis of bacteremia due to diploccocus pneumonia in rabbits. J. Infect. Dis. 127:1-8.

11. Wolfe, R. R., J. H. F. Shaw, and M. J. Durkot. 1985. Effect of sepsis on VLDL kinetics: responses in basal state and during glucose infusion. $A m$. J. Physiol. 248:E732-E740.

12. Kaufmann, R. L., C. F. Matson, and W. R. Beisel. 1976. Hypertriglyceri- demia produced by endotoxin: role of impaired triglyceride disposal mechanisms. J. Infect. Dis. 133:548-555.

13. Rouzer, C. A., and A. Cerami. 1980. Hypertriglyceridemia associated with Trypanosoma brucei infection in rabbits: relative effect of triglyceride removal. Mol. Biochem. Parasitol. 2:31-38.

14. Masoro, E. J. 1977. Fat metabolism in normal and abnormal states. Am. J. Clin. Nutr. 30:1311-1320.

15. Ulevitch, R. J., and C. G. Cochrane. 1978. Role of complement in lethal bacterial lipopolysaccharide-induced hypotensive and coagulative changes. Infect. Immun. 19:204-211.

16. Ulevitch, R. J., A. R. Johnston, and D. B. Weinstein. 1979. New function for high density lipoproteins. Their participation in intravascular reactions of bacterial lipopolysaccharides. J. Clin. Invest. 64:1516-1524.

17. Ulevitch, R. J., A. R. Johnston, and D. B. Weinstein. 1981. New function for high density lipoproteins. Isolation and characterization of a bacterial lipopolysaccharide-high density lipoprotein complex formed in rabbit plasma. $J$. Clin. Invest. 67:827-837.

18. Munford, R. S., C. L. Hall, J. M. Lipton, and J. M. Dietschy. 1982. Biological activity, lipoprotein-binding behavior, and in vivo disposition of extracted, and native forms of Salmonella typhimurium lipopolysaccharides. $J$. Clin. Invest. 70:877-888.

19. Van Lenten, B. J., A. M. Fogelman, M. E. Haberland, and P. A. Edwards. 1986. The role of lipoproteins and receptor-mediated endocytosis in the transport of bacterial lipopolysaccharide. Proc. Natl. Acad. Sci. USA. 83:2704-2708.

20. Harris, H. W., C. Grunfeld, K. R. Feingold, and J. H. Rapp. 1990. Human very low density lipoproteins and chylomicrons can protect against endotoxin-induced death in mice. J. Clin. Invest. 86:696-702.

21. Westphal, V. O., O. Lüderitz, and F. Bister. 1952. Über die extraktion von bakterien mit phenol/wasser. Z. Naturfersch. 7b:148-155.

22. Ulevitch, R. J. 1978. The preparation and characterization of a radioiodinated bacterial lipopolysaccharide. Immunochemistry. 15:157-164.

23. St. Hilaire, R. J., G. T. Hradek, and A. L. Jones. 1983. Hepatic sequestration and biliary secretion of epidermal growth factor: evidence for a high-capacity uptake. Proc. Natl. Acad. Sci. USA. 80:3797-3801.

24. Espevik, T., and J. Nissen-Meyer. 1986. A highly sensitive cell line, WEHI 164 clone 13, for measuring cytotoxic factor/tumor necrosis factor from human monocytes. J. Immunol. Methods. 95:99-105.

25. Mathison, J. C., and R. J. Ulevitch. 1979. The clearance, tissue distribution, and cellular localization of intravenously injected lipopolysaccharide in rabbits. J. Immunol. 123:2133-2143.

26. Zlydasayk, J. C., and R. J. Moon. 1976. Fate of ${ }^{51} \mathrm{Cr}$-labeled lipopolysaccharide in tissue culture cells and livers of normal mice. Infect. Immun. 14:100105.

27. Freudenberg, M. A., N. Freudenberg, and C. Galanos. 1982. Time course of cellular distribution of endotoxin in liver, lungs, and kidneys of rats. Br. J. Exp. Pathol. 63:56-65.

28. Van Bossuyt, H., and E. Wisse. 1988. Cultured Kupffer cells, isolated from human and rat liver biopsies, ingest endotoxin. J. Hepatol. (Amst.). 7:45-56.

29. Hopf, U., G. Ramadori, B. Möller, and C. Galanos. 1984. Hepatocellular clearance function of bacterial lipopolysaccharides and free lipid A in mice with endotoxic shock. Am. J. Emerg. Med. 2:13-19.

30. Beutler, B., I. W. Milsark, and A. C. Cerami. 1985. Passive immunization against cachectin/tumor necrosis factor protects mice from lethal effect of endotoxin. Science (Wash. DC). 229:869-871.

31. Tracey, K. J., Y. Fong, D. G. Hesse, K. R. Manogue, A. T. Lee, G. C. Kuo, S. F. Lowry, and A. Cerami. 1987. Anti-cachectin/TNF monoclonal antibodies prevent septic shock during lethal bacteremia. Nature (Lond.). 330:662-664.

32. Wakabayashi, G., J. A. Gelfand, J. F. Burke, R. C. Thompson, and C. A. Dinarello. 1991. A specific receptor antagonist for interleukin 1 prevents Escherichia coli-induced shock in rabbits. FASEB (Fed. Am. Soc. Exp. Biol.) J. 5:338343.

33. Havel, R. J., and J. P. Kane. 1989. Structure and metabolism of plasma lipoproteins. In Metabolic Basis of Inherited Diseases. C. R. Scriver, A. L. Beaudet, W. S. Sly, and D. Valle, editors. 6th ed. McGraw-Hill, New York 1129-1138.

34. Stalenhoef, A. F. H., M. J. Malloy, J. P. Kane, and R. J. Havel. 1984. Metabolism of apolipoproteins B-48 and B-100 of triglyceride-rich lipoproteins in normal and lipoprotein lipase-deficient humans. Proc. Natl. Acad. Sci. USA. 81:1839-1843.

35. Navab, M., G. P. Hough, R. J. Van Lenten, J. A. Berliner, and A. M. Fogelman. 1988. Low density lipoproteins transfer bacterial lipopolysaccharides across endothelial monolayers in a biologically active form. J. Clin. Invest. 81:601-605.

36. Harris, H. W., E. B. Eichbaum, J. P. Kane, and J. H. Rapp. 1991. Detection of endotoxin in triglyceride-rich lipoproteins in vitro. J. Lab. Clin. Med. 118:186-193.

37. Eichbaum, E. B., H. W. Harris, J. P. Kane, and J. H. Rapp. 1991. Chylomicrons can inhibit endotoxin activity in vitro. J. Surg. Res. 51:413-416.

38. Mathison, J. C., and R. J. Ulevitch. 1981. In vivo interaction of bacterial lipopolysaccharide (LPS) with rabbit platelets: modulation by $\mathrm{C} 3$ and high density lipoproteins. J. Immunol. 126:1575-1580. 
39. Munford, R. S., J. M. Anderson, and J. M. Dietschy. 1981. Sites of tissue binding and uptake in vivo of bacterial lipopolysaccharide-high density lipoprotein complexes. J. Clin. Invest. 68:1503-1513.

40. Flegel, W. A., A. Wölpl, D. N. Männel, and H. Northoff. 1989. Inhibition of endotoxin-induced activation of human monocytes by human lipoproteins. Infect. Immun. 57:2237-2245.

41. Cavaillon, J.-M., C. Fitting, N. Haeffner-Cavaillon, S. J. Kirsch, and H. S. Warren. 1990. Cytokine response by monocytes and macrophages to free and lipoprotein-bound lipopolysaccharide. Infect. Immun. 58:2375-2382.

42. Black, D., P. Tso, S. Weidman, and S. Sabesin. 1983. Intestinal lipoproteins in the rat with D-(+)-galactosamine hepatitis. J. Lipid Res. 24:977-992.

43. Sernatinger, J., A. Hoffman, D. Hardman, J. P. Kane, and J. A. Levy. 1988. Neutralization of mouse xenotropic virus by lipoproteins involves binding to the virions. J. Gen. Virol. 69:2657-2661.

44. Shortridge, K. F., W. K. Ho, A. Oya, and M. Kobayashi. 1975. Studies on the inhibitory activities of human serum lipoproteins for Japanese encephalitis virus. Southeast Asian J. Trop. Med. Public Health. 6:461-466.

45. Chisari, F. V., L. K. Curtiss, and F. C. Jensen. 1981. Physiologic concentrations of normal human plasma lipoproteins inhibit the immortalization of peripheral B lymphocytes by the Epstein-Barr virus. J. Clin. Invest. 68:329-336.

46. Seganti, L., M. Grassi, P. Mastromarino, A. Pan'a, F. Superti, and N. Orsi. 1983. Activity of human serum lipoproteins on the infectivity of rhabdoviruses Microbiology (Wash. DC). 6:91-99.

47. Owens, R. J., G. M. Anantharamaiah, J. B. Kahlon, R. V. Srinivas, R. W Compans, and J. P. Segrest. 1990. Apolipoprotein A-1 and its amphipathic helix peptide analogues inhibit human immunodeficiency virus-induced syncytium formation. J. Clin. Invest. 86:1142-1150.

48. Rifkin, M. R. 1978. Identification of the trypanocidal factor in normal human serum: high density lipoprotein. Proc. Natl. Acad. Sci. USA. 75:34503454.

49. Prioli, R. P., I. Rosenberg, S. Shivakumar, and M. E. Pereira. 1988. Spe- cific binding of human plasma high density lipoprotein (cruzin ) to Trypanosoma cruzi. Mol. Biochem. Parasitol. 28:257-263.

50. Hajduk, S. L., D. R. Moore, J. Vasudevacharya, H. Siqueira, A. F. Torri, E. M. Tytler, and J. D. Esko. 1989. Lysis of Trypanosoma brucei by a toxic subspecies of human high density lipoprotein. J. Biol. Chem. 264:5210-5217.

51. Terkettaub, R., L. K. Curtiss, A. J. Tenner, and M. H. Ginsberg. 1984. Lipoproteins containing apoprotein B are a major regulator of neutrophil responses to monosodium urate crystals. J. Clin. Invest. 73:1719-1730.

52. Patton, J. S., H. M. Shepard, H. Wilking, G. Lewis, B. B. Aggarwal, T. E. Eessalu, L. A. Gavin, and C. Grunfeld. 1986. Interferons and tumor necrosis factors have similar catabolic effects on $3 \mathrm{~T} 3 \mathrm{Ll}$ cells. Proc. Natl. Acad. Sci. USA. 83:8313-8317.

53. Pekala, P. H., M. Kawakami, C. W. Angus, M. D. Lane, and A. Cerami. 1983. Selective inhibition of synthesis of enzymes for de novo fatty acid biosynthesis by an endotoxin-induced mediator from exudate cells. Proc. Natl. Acad. Sci. - USA. 80:2743-2747.

54. Feingold, K. R., and C. Grunfeld. 1987. Tumor necrosis factor-alpha stimulates hepatic lipogenesis in the rat in vivo. J. Clin. Invest. 80:184-190.

55. Feingold, K. R., M. K. Serio, S. Adi, A. H. Moser, and C. Grunfeld. 1989. Tumor necrosis factor stimulates hepatic lipid synthesis and secretion. Endocrinology. 124:2336-2342.

56. Feingold, K. R., M. Soued, S. Adi, I. Staprans, R. Neese, J. Shigenaga, W. Doerrler, A. Moser, C. A. Dinarello, and C. Grunfeld. 1991. Effect of interleukin1 on lipid metabolism in the rat: similarities to and differences from tumor necrosis factor. Arterioscler. Thromb. 11:495-500.

57. Beutler, B. A., and A. Cerami. 1985. Recombinant interleukin 1 suppresses lipoprotein lipase activity in 3T3-L1 cells. J. Immunol. 135:3969-3971.

58. Grunfeld, C., S. Ade, M. Soued, A. Moser, W. Fiers, and K. R. Feingold. 1990. Search for mediators of the lipogenic effects of tumor necrosis factor: potential role for Interleukin 6. Cancer Res. 50:4233-4238. 